\title{
HOW TO INCREASE JOB SATISFACTION IN BANKING SECTOR? THE EFFECTS OF PERCEIVED ORGANIZATIONAL AND SOCIAL SUPPORT, AND EMOTIONAL INTELLIGENCE
}

\author{
*Mihriban CINDILOGLU \\ **Sema POLATCI \\ *Hitit University, Turkey \\ **Gaziosmanpaşa University, Turkey
}

\begin{abstract}
This study examines the effects of perceived organizational and social support and emotional intelligence of banking sector employees' on job satisfaction. Survey responses from 223 bank employees in Turkey were analyzed and which factor effects job satisfaction more was determined. When the research results are examined, the $\mathrm{H} 1$ hypothesis established on the assumption that perceived organizational support has a positive effect on job satisfaction has been supported. The $\mathrm{H} 2$ hypothesis based on the assumption that perceived social support has a positive effect on job satisfaction is rejected. H3 hypothesis based on the idea that emotional intelligence has a positive effect on job satisfaction has been rejected. The findings of this research have important theoretical and practical implications for banking sector. Applied implications of the results are discussed.
\end{abstract}

\section{INTRODUCTION}

In the literature several studies have been conducted to look into the relationship between employees' level of job satisfaction and performance (Miller and Muthard, 1965; Judge, et al., 2001; Iaffaldano and Muchinsky, 1985). According to these studies it has been accepted that employee satisfaction correlates with employee performance, as in the case with firm performance. But there isn't any certain formula for job satisfaction.

Job satisfaction is a great problem especially in many sectors like banking sector. Stressful working conditions come together with the stress of money and effect employees negatively. So it is difficult but at the same time important to keep banking sector employees satisfied. Job satisfaction of bank employees and also their performance and intention to leave the organization are specific outcomes associated with physical, psychological and social variables.

An increasing body of research has linked poor working conditions in banks and poor job outcomes in general. On the other hand, there is no evidence that work conditions guarantee the employee well-being or performance. In this case why do some employees feel good with their work and accomplish better than others? Lots of studies searched the answer of this question on physical factors and work environments. In this study we researched a factor that is not physical side, also the psychological side of the work environment, perceived organizational support. Together with perceived organizational support, the effects of personal characteristic, emotional intelligence and social interaction ability perceived social support on job satisfaction had been studied. So we researched that which factors shapes the job satisfaction of banking employees?

An ongoing focus on job satisfaction of bank employee's outcome is needed because of the current problems of banking sector about unsatisfied employees. Specially, this paper set out to answer the following questions; (a) What is the overall satisfaction level of employees at the bank? (b) Does the perceived organizational support, perceived social support, and emotional intelligence affect job satisfaction? (c) Which variable affect the job satisfaction level of bank employees more?

The context of the Turkish banking system may pose unique challenges for employees depending on the banks in which they work. It is important to understand the effects of the variables on bank employees' job satisfaction. 


\section{Literature Review Job Satisfaction}

The concept of job satisfaction was developed by Elton Mayo and his colleagues in Hawthorne study, in Chicago Western Electric Company. The study was conducted in the late 1920s and early 1930s. The result of this study showed that behaviors of employees in the workplace can be impacted upon by their feelings. So the social interactions and personal characteristics of the employees are the core bases of their satisfaction, and their personal performance (Robbins, Odendaal, and Roodt, 2003).

Job satisfaction is a combination of psychological, physical and environmental factors that allow the people who work in organization to feel satisfied with his/her work or not. Job satisfaction refers to the degree to which people like their job (Spector, 1997: 11v) or an individual's general attitude toward his or her job. A person with a high level of job satisfaction holds positive attitudes toward the job, while a person who is dissatisfied with his or her job holds negative attitudes toward the job (Pranit, 2010: 67). Job satisfaction is described by Mirzaii and this colleagues (2014) as one of the crucial ingredients for job accomplishment which related to higher productivity and also intrinsic motivation of an employee.

There are several studies showing that the physical factors are crucial factors which influence the level of satisfaction of employees (Agbozo, et al., 2017). These studies asserts that the productivity of employees is determined by the physical factors in the work places. The physical factors that are crucial for job satisfaction are working environment, management practices, organizational culture, etc. ( Agbozo, et al., 2017). But together with physical conditions, the psychological, social and the personal characteristics play more important and persistent role on job satisfaction. This study examines the effects of them on banking sector employees' job satisfaction.

\section{Perceived Organizational Support and Job Satisfaction}

Perceived organizational support as a psychological work environment factor that can be considered as an element of the workplace which affect how the worker feels. These psychological work environment factors affect the level of contentment of an employee and in effect impacts on his/her performance (Agbozo, et al., 2017).

The concept of perceived organizational support has been developed in early 80's, and researched in the field of psychology and management (Rhoades and Eisenberger, 2002). Based on social exchange theory perceived organizational support is defined as employees' formation of global beliefs pertaining to how much the organization cares about their well-being and values their contributions (Martin, 1995; Randall et al., 1999), or shortly how much the organization values its employees. Eisenberger and his colleagues (1986) described the perceived organizational support as the extent to which the organization values employees' contributions and cares about their well-being.

In today's organizations because of the recognized importance of human resource, intensive competition and the new generation's unique characteristics, the concept of perceived organizational support is more important than before. Because nowadays employees prefer to work in organizations which value its employees, rather than just working for a particular organization only for earning money (Osman et al., 2015: 176). Perceived organizational support includes the aspects of justice, support from supervisors, reward and desirable job conditions.

The organizational support perception has been the crucial aspect of understanding why individuals have job satisfaction. In other words, researches showed that one of the important factors that affect the satisfactions of employees is perceived organizational support (Rhoades, Eisenberger and Armeli, 2001). It seems that if an organization gives adequate training, resources and support from management, it is more likely that members of these organization would be pleasant to work in that organization. In various researches, it was proven that there is a positively relationship between perceived organizational support and job satisfaction (Patrick and Laschinger, 2006; Gillet, et al., 2013). Further, the results of the researches determine that when the organization values its employee's, the tendency of the employees to satisfy from the job will be higher. In the lights of these researches it can be hypothesized that:

\section{H1: Perceived organizational support positively effects job satisfaction.}




\section{Perceived Social Support and Job Satisfaction}

Social factors affecting workers are significantly influential on the relationships in work and private lives. Social environment factors like relationships with others in workplace and rest of the life, communication styles, work-life balance of worker, resistance to conflict and negative situations is crucial for employees on their feelings, attitudes, perceptions and behaviors. As a social factor, the perceived social support is important for an employee's feeling about work and private life, and about the performance he/she exhibit in all areas.

Unlike the perceived organizational support, perceived social support comes not from the organization or working conditions, but from worker' family, friends and social networks. The most important social support source is the family, then the social relations and friends comes.

Researchers suggested that high levels of perceived social support positively related with organizational commitment, job satisfaction, motivation, performance, life satisfaction, coping with difficult conditions, and negatively related with job stress, burnout and conflict (Cieslak, et al., 2007: 85; Lindorff, 2001: 281; Bhaunthumnavian, 2003: 80; Daalen, et al., 2006: 464-465; Kirmeyer ve Lin, 1987: 138; Clara, et al., 2003: 265).

Focusing on the factors which effect the job satisfaction, perceived social support is another variable that also play significant role. The researchers determined positive relationship between perceived social support and job satisfaction (Singh and Singhi, 2015; Brandley and Cartwright, 2002; Brough and Pears, 2004; Adams, et al., 1996). This can be assessed as follows: employees are more satisfied with their job when they perceive support from their social environment. Therefore the hypothesis below was developed:

H2: Perceived social support positively effects job satisfaction.

\section{Emotional Intelligence and Job Satisfaction}

Emotions are the important parts of human beings, and they affect the actions and motivations for behaviors (Stanley and Burrows, 2005). Mayer and Salovey (1997: 10) described the emotional intelligence as "the ability to perceive accurately, appraise, and express emotion; the ability to access and/or generate feelings when they facilitate thought; the ability to understand emotion and emotional knowledge; and the ability to regulate emotions to promote emotional and intellectual growth".

Emotional intelligence (EI) can play a significant role in the work environment (Goleman, Boyatzis, and McKee, 2002; Wong and Law, 2002). Specifically, researchers assert that employees' emotional intelligence can predict work related outcomes, especially job satisfaction (Brunetto, et al., 2012; Kafetsios and Zampetakis, 2008; Güleryüz, et al., 2008; Bachman, Stein, Campbell, and Sitarenios, 2000; Prati, Douglas, Ferris, Ammeter, and Buckley, 2003; Wong and Law, 2002). Even Daus and Ashkanasy (2005) and Van Rooy and Viswesvaran (2004) pointed out that emotional intelligence is an important predictor of key organizational outcomes including job satisfaction. Employees with high levels of emotional intelligence are more likely to have higher levels of job satisfaction because they are more adept at appraising and regulating their own emotions than employees who have low levels of emotional intelligence. Employees who are emotionally intelligence are better at identifying feelings of frustration and stress, and subsequently, regulating those emotions to reduce stress. Employees with high emotional intelligence are more resilient because they are able to understand the causes of stress and develop strategies and perseverance to deal with the negative consequences of stress (Cooper and Sawaf, 1997).

Sy and his colleagues (2006) examined the relationships among employees' emotional intelligence, their manager's emotional intelligence, employees' job satisfaction, and performance. They found that employees' emotional intelligence was positively associated with job satisfaction and performance. In addition, manager's emotional intelligence had a more positive correlation with job satisfaction for employees with low emotional intelligence than for those with high emotional intelligence. Therefore we expected that there would be a relationship between banking sector employees' emotional intelligence and job satisfaction.

H3: Emotional intelligence positively effects job satisfaction. 


\section{RESEARCH METHODOLOGY Research Sample}

The study sample consisted of bank employees in Çorum province from Turkey. According to the data of the Banks Association of Turkey that has a total of 12 banks and 29 bank branches in the city center. According to the information received from bank branch officials, there are 400 employees in banking sector in the province center. It was determined that the sample size to represent this universe was 209 in 95\% confidence interval and 261 in 99\% confidence interval (Gürbüz and Şahin, 2014: 126). Based on volunteerism, 249 questionnaires returned from the employees. Incorrect or incompletely filled out questionnaires were removed and 223 questionnaires were analyzed. 58.6\% (133) of the sample were male, the average age was 34 and the ages ranged from 18 to 57 years. $67.7 \%$ (151) of the participants were married, $42.6 \%$ (95) undergraduate graduates and 35.9\% (80) have 6-10 years of professional experience.

\section{Measures}

The survey form used in the research consists of five parts. In the first part, "Perceived Organizational Support Scale"; "Perceived Social Support Scale" in the second section, "Emotional Intelligence Scale" in the third section and "Job Satisfaction Scale" in the fourth section; used. The fifth part of the questionnaire form, contains questions about the demographic characteristics of the participants. A 5point Likert scale is used for all scales.

Perceived Organizational Support Scale: The 8 items scale developed by Eisenberger et al. (1997) was used to determine the level of perceived organizational support of participants in the study. In the reliability analysis performed by Eisenberger et al. (1997), the Cronbach's alpha coefficient was found to be 0.90 . The Turkish version of the scale was used by Polatc1 (2015) and the Cronbach alpha coefficient was 0.84 . In this study, the Cronbach alpha coefficient of scale was determined as .908 .

Confirmatory factor analysis was conducted to test the validity of the perceived organizational support scale. According to the confirmatory factor analysis, "X2: 38,070 (df: 16) - X2 / df: 2,379 - RMSEA :, 079 - GFI :, 960 - CFI :, 984 - NFI :, 973". It is possible to say that the values of goodness of fit of the scale are acceptable. (Good Fit: X2 /df: $\leq 5$, RMSEA $\leq 0.08$, GFI $\geq 0.90$, CFI $\geq 0.90$, NFI $\geq 0.90$ - Çokluk, et al., 2014: 271-272).

Perceived Social Support Scale: In order to measure the level of perceived social support, a 12 items social support perception scale developed by Zimet et al. (1988) was used. The scale examines the perceived social support in 3 dimensions as support from the family, friends and a special person. The total Cronbach's alpha coefficient of the scale developed by Zimet et al. (1988) is 0.88. The Turkish version of the scale was developed by Eker et al. (2001) and the total scale was found to be above the Cronbach alpha coefficient of .80. The Cronbach alpha coefficient of this scale was 0.965 in this study.

Confirmatory factor analysis was conducted to test the validity of the perceived social support scale. According to the confirmatory factor analysis, "X2: 85,007 (df: 36) - X2 / df: 2,361 - RMSEA :, 078 GFI :, 945 - CFI :, 984 - NFI :, 973”. It is possible to say that the values of goodness of fit of the scale are acceptable.

Emotional Intelligence Scale: The scale used to measure levels of emotional intelligence Schutte et al. (1998). However, in this study, the 12 items version abbreviated by Chan (2006) was used. The scale consists of 4 dimensions; emotional evaluation, empathic sensitivity, positive emotional management and positive use of feelings. The reliability coefficients of the scale were 0.74 for emotional evaluation, 0.76 for empathic sensitivity subscale, 0.75 for positive emotional management subscale, and 0.72 for positive emotion subscale in Chan (2006) study. In this study, the Cronbach's alpha coefficients for the subscales were determined to be 0.935 for empathic sensitivity, 0.924 for positive emotional management, and 0.908 for positive emotional use for emotional evaluation. The overall reliability coefficient of the scale was .896. In the reliability analysis conducted by Polatci and Özyer (2015), the general Cronbach alpha coefficient was found to be 0.94 .

Confirmatory factor analysis was conducted to test the validity of the emotional intelligence scale. According to confirmatory factor analysis with four factor structure, " $\mathrm{X}^{2}: 138,961$ (df: 48) - X2 / df: 
2,896 - RMSEA :,072 - GFI :,910 - CFI :,960 - NFI :,940”. It is possible to say that the values of goodness of fit of the scale are acceptable.

Job Satisfaction Scale: The 5 items scale developed by Brayfield and Rothe (1951) was used to determine the job satisfaction level of participants in the study. In the reliability analysis conducted by Brayfield and Rothe (1951), the Cronbach alpha coefficient was found to be 77. The scale was adapted by Turkish Keser (2003) and the Cronbach alpha coefficient was 75. In this study, Cronbach alpha coefficient of scale was found to be 0.852 .

Confirmatory factor analysis was conducted to test the validity of the job satisfaction scale. According to the confirmatory factor analysis, "X2: 3,630 (df: 3) - X² / df: 1,210 - RMSEA:, 031 - GFI :, 993 - CFI :, 999 - NFI :, 994". It is possible to say that the values of the appropriateness of the scale are acceptable.

\section{Results}

The mean and standard deviations of the variables and the correlation coefficients are shown in Table 1.

Table 1: Mean, Standard Deviation and Correlation Values of Variables

\begin{tabular}{lllllll}
\hline & Mean & SD. & $\mathbf{1}$ & $\mathbf{2}$ & $\mathbf{3}$ & $\mathbf{4}$ \\
\hline Perceived Organizational Support & 3,20 &, 905 & $\mathbf{( , 9 0 8 )}$ & & & \\
\hline Perceived Social Support & 3,80 &, 874 &, 065 & $(\mathbf{9 6 5})$ & & \\
\hline Emotional Intelligence & 3,64 &, 651 &,- 057 &, $417^{* *}$ & $(\mathbf{, 8 9 6})$ & \\
\hline Job Satisfaction & 3,25 &, 934 &, $374 * *$ &, $142^{*}$ &, 047 & $(, \mathbf{8 5 2})$ \\
\hline$\quad * p<0.05, * * p<01,()$ Reliability & & & & & &
\end{tabular}

${ }^{*} p<0.05, * * p<0.01$, ( ) Reliability

In Table 1, there are positive relationships between perceived social support and emotional intelligence, perceived social support and job satisfaction, perceived organizational support and job satisfaction, as a result of the correlation analysis between variables. No statistically significant relationship was found between the other variables.

The research in banking sector determined that there is no significantly difference between female and male workers' job satisfaction levels $(\mathrm{t}=-1,417 ; \mathrm{p}=0,556 ; \mathrm{F}=.348)$. On the contrary, Hunjra and his colleagues (2010) conducted the research in banking sector and determined that female and male workers in banking sector have significantly different level of job satisfaction.

Regression analyzes were conducted to determine whether perceived organizational and social support and emotional intelligence affected job satisfaction. The study results are given in Model 1.

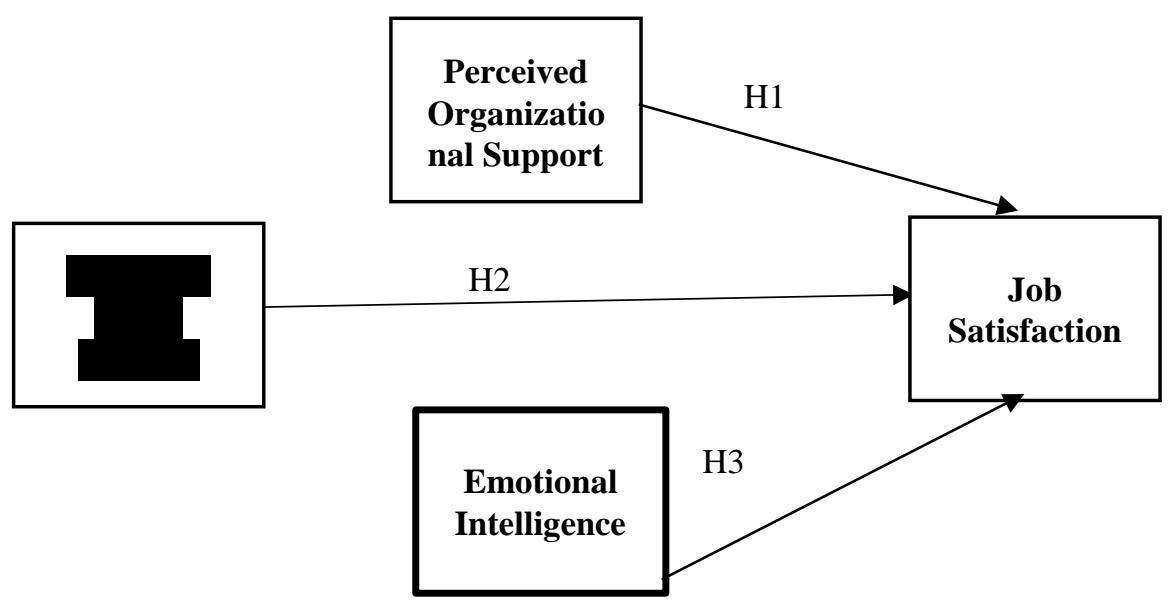

Model 1: Research Model 
Table 2: Results of Multiple Regression Analysis ( $\mathbf{N}=\mathbf{2 2 3})$

\begin{tabular}{lccc}
\hline Variables & B & S.E. & $\boldsymbol{\beta}$ \\
\hline Perceived Organizational Support & .370 & .068 & $.346^{* *}$ \\
\hline Perceived Social Support & .096 & .072 & .093 \\
\hline Emotional Intelligence & .034 & .100 & .023 \\
\hline Job Satisfaction & 1.579 & .415 &
\end{tabular}

Multiple regression analysis was performed to test hypotheses of the study. The effect of perceived organizational support on job satisfaction was examined in order to test the first hypothesis of the research. As a result of regression analysis, perceived organizational support positively effects job satisfaction level. According to this result, H1 hypothesis is supported. To test the second hypothesis of the study, the effect of perceived social support on job satisfaction was examined. As a result of regression analysis, social support does not have a significant effect on job satisfaction. To test the third hypothesis of the research, the effect of emotional intelligence on job satisfaction was examined. As a result of the regression analysis, it was found that emotional intelligence had no effect on job satisfaction. According to this result, $\mathrm{H} 2$ and $\mathrm{H} 3$ hypotheses are rejected.

Tolerance and VIF values are examined to determine whether there is a multi collinearity problem between variables. This value is determined by evaluating the value "1 $-\mathrm{R}^{2 "}$ (Gürbüz and Şahin, 2014: 269). It was 0.865 in this study (Tolerance, respectively, $989-, 807-, 810$ ). When we look at the tolerance values, the values for the independent variables are greater than 0.865 . For this reason, our model showed that there was no multi collinearity problem (Tolerance> .2, VIF <10).

\section{CONCLUSION AND DISCUSSIONS}

The purpose of the study was to determine the impact of perceived organizational support, social support and emotional intelligence on job satisfaction. When the research results are examined, the H1 hypothesis established on the assumption that perceived organizational support has a positive effect on job satisfaction has been supported. According to this conclusion, if the organization values the employees and makes them feel that, it will affect their perceptions regarding job satisfaction.

The $\mathrm{H} 2$ hypothesis based on the assumption that perceived social support has a positive effect on job satisfaction is rejected. According to this result, perceived social support has no significant effect on job satisfaction. It is thought that this situation is related to bank employees. Compared with other sectors, it can be assumed that the bank employees are working intensively in the temp desk until the end of working hours. This situation prevents employees from taking the time to socialize. On the other hand, exactly determined job descriptions prevent employees from social interactions, too. It is thought that there is no significant effect of perceived social support on job satisfaction because of these. In addition to the nonsensical effect of perceived social support on job satisfaction, it can be suggested that social support perception on the same sample can be examined comparatively with the effect on life satisfaction.

Finally, the $\mathrm{H} 3$ hypothesis based on the idea that emotional intelligence has a positive effect on job satisfaction has been rejected. According to this result, emotional intelligence has no significant effect on job satisfaction. Emotional intelligence is expressed as the ability of emotions to be used effectively in social relations, as well as being able to manage own emotions and the emotions of others. According to the results, the high or low levels of emotional intelligence of employees do not affect job satisfaction. This result showed that, the solid job descriptions prevent employees' job satisfactions according to their emotional intelligence.

Due to time and financial constraints, the research was limited to Çorum province center. In this respect, it can be expressed as a suggestion to analyze this model in different country and sectors, in terms of determining possible differences in the model. Due to the constraints about the sample, it is not possible to generalize the results. Repeating the study on different and larger samples makes it possible to achieve generalizable results. The results of research models can be determined by comparing studies on different sectors. 


\section{REFERENCES}

Adams, G. A., King, L. A., \& King, D. W. (1996). Relationships of job and family involvement, family social support, and work-family conflict with job and life satisfaction. Journal of Applied Psychology, 81(4), 411.

Agbozo, G. K., Owusu, I. S., Hoedoafia, M. A., \& Atakorah, Y. B. (2017). The effect of work environment on job satisfaction: Evidence from the banking sector in Ghana. Journal of Human Resource Management, 5(1), 12-18.

Bachman, J., Stein, S., Campbell, K., \& Sitarenios, G. (2000). Emotional intelligence in the collection of debt. International Journal of Selection and Assessment, 8, 176-182.

Baron, M. R. \& Kenny A. D. (1986). "The Moderator- Mediator Variable Distinction in Social Psychological Research: Conceptual, Strategic, And Statistical Considerations". Journal Of Personality And Social Psychology, 51(6): 1173-1182

Bhanthumnavian, D. (2003). Perceived social support from supervisor and group members' psychological and situational characteristics as predictors of subordinate performance in Thai work units. Human Resource Development Quarterly, 14(1), 79-97.

Bradley, J. R., \& Cartwright, S. (2002). Social support, job stress, health, and job satisfaction among nurses in the United Kingdom. International Journal of Stress Management, 9(3), 163-182.

Brayfield, A. H. ve Rothe, H. F. (1951). "An Index of Job Satisfaction”. Journal of Applied Psychology. 35: 307-311.

Brough, P., \& Pears, J. (2004). Evaluating the influence of the type of social support on job satisfaction and work related psychological well-being. International Journal of Organisational Behaviour, 8(2), 472485 .

Brunetto, Y., Teo, S. T., Shacklock, K., \& Farr-Wharton, R. (2012). Emotional intelligence, job satisfaction, well-being and engagement: Explaining organisational commitment and turnover intentions in policing. Human Resource Management Journal, 22(4), 428-441.

Cieslak, R., Knoll, N. \& Luszczynska, A. (2007). Reciprocal relations among job demands, job control, and social support are moderated by neuroticism: A cross-lagged analysis. Journal of Vocational Behavior, 71(1), 84-96.

Chan, D. W. (2006). "Emotional Intelligence and Components of Burnout Among Chinese Secondary School Teachers in Hong Kong”. Teaching and Teacher Education, 22(8), 1042-1054.

Clara, I. P., Cox, B. J., Enns, M. W., Murray, L. T. \& Torqrudc, L. J. (2003). Confirmatory factor analysis of the multidimensional scale of perceived social support in clinically distressed and student samples. Journal of Personality Assessment, 81(3), 265-270.

Çokluk, Ö., Şekercioğlu, G. \& Büyüköztürk Ş. (2014). Sosyal Bilimler İçin Çok Değişkenli İstatistik SPSS ve LISREL Uygulamaları. Ankara: Pegem Akademi.

Cooper, R. K., \& Sawaf, A. (1997). Executive EQ: Emotional intelligence in leaders and organizations. NY: Grosset/Putnam.

Daalen, G. V., Willemsen, T. M. \& Sanders, K. (2006). Reducing work-family conflict through different sources of social support. Journal of Vocational Behavior, 69(3), 462-476.

Daus, C. S., \& Ashkanasy, N. M. (2005). The case for the ability-based model of emotional intelligence in organizational behaviour. Journal of Organizational Behavior, 26, 453-466.

Eisenberger, R; Cummings, J.; Armeli, S. \& Lynch, P. (1997). "Perceived Organizational Support, Discretionary Treatment, and Job Satisfaction". Journal of Applied Psychology, vol.82, No. 5, pp. 812820 .

Eisenberger, R., Huntington, R., Hutchison, S., \& Sowa, D. (1986). Perceived organizational support. Journal of Applied Psychology, 71, 500-507.

Eker, D., Arkar, H. \& Yaldız, H. (2001), “Çok Boyutlu Algılanan Sosyal Destek Ölçeği'nin Gözden Geçirilmiş Formunun Faktör Yapısı, Geçerlik ve Güvenilirliği”, Türk Psikoyatri Dergisi, 12(1), 17-25. 
Gillet, N., Colombat, P., Michinov, E., Pronost, A. M., \& Fouquereau, E. (2013). Procedural justice, supervisor autonomy support, work satisfaction, organizational identification and job performance: The mediating role of need satisfaction and perceived organizational support. Journal of Advanced Nursing, 69(11), 2560-2571.

Goleman, D., Boyatzis, R., \& McKee, A. (2002). Primal leadership: Realizing the power of emotional intelligence. Boston, MA: Harvard Business School Press.

Güleryüz, G., Güney, S., Aydın, E.M. \& Aşan, Ö. (2008). The mediating effect of job satisfaction between emotional intelligence and organisational commitment of nurses: A questionnaire survey. International Journal of Nursing Studies, 45(11), 1625-1635.

Gürbüz, S. \& Şahin, F. 2014, Sosyal Bilimlerde Araştırma Yöntemleri, FelsefeYöntem-Analiz, Seçkin, Ankara.

Hunjra, A. I., Chani, D., Aslam, S., Azam, M., \& Rehman, K. (2010). Factors effecting job satisfaction of employees in Pakistani banking sector. African Journal of Business Management, 4(10), 2157-2163

Iaffaldano, M. T., \& Muchinsky, P. M. (1985). Job satisfaction and job performance: A metaanalysis. Psychological Bulletin, 97(2), 251.

Judge, T. A., Thoresen, C. J., Bono, J. E., \& Patton, G. K. (2001). The job satisfaction-job performance relationship: A qualitative and quantitative review. Psychological Bulletin, 127(3), 376.

Kafetsios, K., \& Zampetakis, L. A. (2008). Emotional intelligence and job satisfaction: Testing the mediatory role of positive and negative affect at work. Personality and Individual Differences, 44(3), $712-722$.

Keser, A. (2003). Çalışmanın Anlamı, İnsan Yaşamındaki Yeri ve Yaşam Doyumu Üzerine Bir Uygulama. (Yayınlanmamış Doktora Tezi). Bursa: Uludağ Üniversitesi Sosyal Bilimler Enstitüsü.

Kirmeyer, S. \& Lin, T. (1987). Social support: Its relationship to observed communication with peers and superiors. Academy of Management Journal, 30(1), 138-151.

Lindorff, M. (2001). Are they lonely at the top? Social relationships and social support among Australian managers. Work \& Stress, 15(3), 274-282.

Martin, R. (1995). The roles of organizational support and justice during a layoff. Academy of Management Journal, 89-93.

Mayer, J. \& Salovey, P. (1997). What is emotional intelligence? in P. Salovey \& D. Sluyter (eds), Emotional Development and Emotional Intelligence: Educational Implications, New York: Basic Books.

Miller, L. A. \& Muthard, J. E. (1965). Job satisfaction and counselor performance in state rehabilitation agencies. Journal of Applied Psychology, 49, 280-283.

Mirzaii, L. H., Riazi, Z., Vares, M. et al. (2014). The relations between working life quality and coping with stress and job satisfaction in exceptional schools' teachers. Arabian Journal of Business and Management Review (OMAN Chapter), 4(1).

Osman, A., Othman, Y. H., Rana, S. S., Solaiman, M., \& Lal, B. (2015). The influence of job satisfaction, job motivation \& perceived organizational support towards organizational citizenship behavior (OCB): A perspective of American-based organization in Kulim, Malaysia. Asian Social Science, 11(21), 174-182.

Patrick, A., \& Laschinger, H. K. S. (2006). The effect of structural empowerment and perceived organizational support on middle level nurse managers' role satisfaction. Journal of Nursing Management, 14(1), 13-22.

Polatcı, S (2015). "Örgütsel ve Sosyal Destek Algılarının Yaşam Tatmini Üzerindeki Etkisi: İş ve Evlilik Tatmininin Aracılık Rolü”. Ekonomik ve Sosyal Araştırmalar Dergisi, cilt.11, Yıl 11, S. 2, ss. 25-44.

Polatc1, S. \& Özyer, K. (2015). "Duygusal Emek Stratejilerinin Duygusal Zekanın Tükenmişliğe Etkisindeki Aracılık Rolü”. AİB̈̈ Sosyal Bilimler Enstitüsü Dergisi, 2015, Cilt:15, Y11:15, Sayı:3, 15: 131-156.

Pranit, K. (2010). Organisational Behaviour. Gyan Publishing House. 
Prati, L. M., Douglas, C., Ferris, G. R., Ammeter, A. P., \& Buckley, M. R. (2003). Emotional intelligence, leadership effectiveness, and team outcomes. International Journal of Organizational Analysis, 11, 21-41.

Randall, M. L., Cropanzano, R., Bormann, C. A. \& Birjulin, A. (1999). Organizational politics and organizational support as predictors of work attitudes, job performance, and organizational citizenship behavior. Journal of Organizaitonal Behavior, 20, 159-174.

Rhoades, L, \& Eisenberger, R. (2002). Perceived organizational support: A review of the literature. Journal of Applied Psychology, 87, 698-714.

Rhoades, L., Eisenberger, R. \& Armeli, S. (2001). Affective commitment to the organization: The contribution of perceived organizational support. Journal of Applied Psychology, 86, 825-836.

Robbins, S. P., Odendaal, A., \& Roodt, G. (2003). Organizational Behavior. Global and Southern African Perspectives 9th ed. Cape Town: Pearson Education.

Schutte, N. S., Malouff, J. M., Hall, L. E., Haggerty, D. J., Cooper, J. T., Golden, C. \& Dornheim, L. (1998). "Development and Validation of A Measure of Emotional Intelligence". Personality and Individual Differences, 25 (2), 167- 177.

Singh, A. P., \& Singhi, N. (2015). Organizational role stress and social support as predictors of job satisfaction among managerial personnel. Journal of Psychosocial Research, 10(1), 1.

Spector, P. E. (1997). Job satisfaction: Application, assessment, causes, and consequences (Vol. 3). Sage publications.

Stanley, R.O. \& Burrows, G. D. (2005). The role of stress in mental illness: The practice. in C.L. Cooper (ed.), Handbook of Stress Medicine and Health, London: CRC Press.

Sy, T., Tram, S., \& O'Hara, L. A. (2006). Relation of employee and manager emotional intelligence to job satisfaction and performance. Journal of Vocational Behavior, 68(3), 461-473.

Van Rooy, D. L., \& Viswesvaran, C. (2004). Emotional intelligence: A meta-analytic investigation of predictive validity and nomological net. Journal of Vocational Behavior, 65(1), 71-95.

Zimet, G. D., Dahlem, N. W., Zimet, S. G. \& Farley, G. K. (1988), “The Multidimensional Scale of Perceived Social Support", Journal of Personality Assessment, 52(1), 30-41

Wong, C., \& Law, K. S. (2002). The effect of leader and follower emotional intelligence on performance and attitude: An exploratory study. Leadership Quarterly, 23, 243-274. 